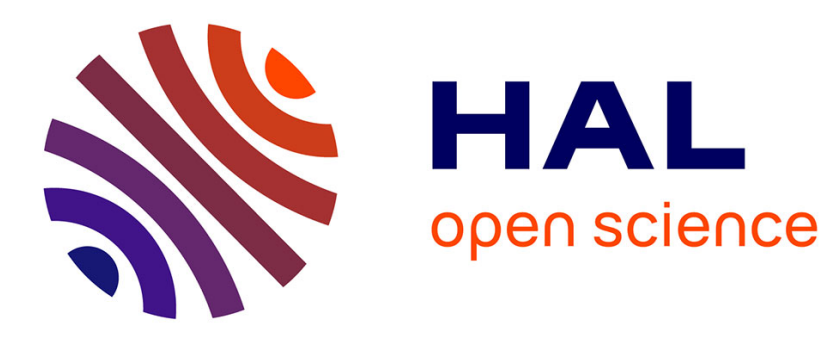

\title{
Urbanization effects on wild bee carbon and nitrogen stable isotope ratios in the Paris region
}

\author{
Aleksandar Rankovic, Benoit Geslin, Adrien Perrard, Anne Barbillon, \\ Véronique Vaury, Luc Abbadie, Isabelle Dajoz
}

\section{To cite this version:}

Aleksandar Rankovic, Benoit Geslin, Adrien Perrard, Anne Barbillon, Véronique Vaury, et al.. Urbanization effects on wild bee carbon and nitrogen stable isotope ratios in the Paris region. Acta Oecologica, 2020, 105, pp.103545. 10.1016/j.actao.2020.103545 . hal-02555287

\section{HAL Id: hal-02555287 \\ https://hal.science/hal-02555287}

Submitted on 15 Mar 2021

HAL is a multi-disciplinary open access archive for the deposit and dissemination of scientific research documents, whether they are published or not. The documents may come from teaching and research institutions in France or abroad, or from public or private research centers.
L'archive ouverte pluridisciplinaire HAL, est destinée au dépôt et à la diffusion de documents scientifiques de niveau recherche, publiés ou non, émanant des établissements d'enseignement et de recherche français ou étrangers, des laboratoires publics ou privés. 


\title{
Urbanization effects on wild bee carbon and nitrogen stable isotope ratios in the Paris region
}

\author{
Aleksandar Rankovic $^{\mathrm{a}, \mathrm{b}, 1, *}$, Benoît Geslin ${ }^{\mathrm{c}, 1, * *}$, Adrien Perrard $^{\mathrm{a}}$, Anne Barbillon ${ }^{\mathrm{a}}$, \\ Véronique Vaury ${ }^{\mathrm{a}}$, Luc Abbadie ${ }^{\mathrm{a}}$, Isabelle Dajoz ${ }^{\mathrm{a}}$ \\ ${ }^{a}$ Institute of Ecology and Environmental Sciences - IEES Paris (UMR 7618, UPMC, CNRS, IRD, INRA, UPEC, Paris Diderot), Sorbonne Université, 4 Place Jussieu, 75005, \\ Paris, France \\ b Institut du Développement durable et des Relations Internationales, Sciences Po, 27 Rue Saint-Guillaume, 75007, Paris, France \\ ${ }^{\mathrm{c}}$ Aix Marseille Université, Avignon Université, CNRS, IRD, IMBE, Marseille, France
}

\begin{abstract}
A B S T R A C T
Urban environments have been shown to have profound, yet still poorly understood effects on key ecosystem processes such as carbon (C) and nitrogen (N) cycling, as well as for key aspects of organism ecology, such as community assembly and network interactions. The study of natural abundances of $\mathrm{C}$ and $\mathrm{N}$ stable isotopes, ${ }^{13} \mathrm{C}$ and ${ }^{15} \mathrm{~N}$, can help infer mechanistic hypotheses on ecosystem processes at play in urban environments. No existing study has investigated whether a visible urban effect on soil and plant $\mathrm{C}$ and $\mathrm{N}$ biogeochemistry is being transferred to the animal compartment of urban ecosystems through trophic interactions. Here, we report ${ }^{13} \mathrm{C}$ and ${ }^{15} \mathrm{~N}$ natural abundance values measured on three pollinating species of wild bees (Lasioglossum laticeps, Lasioglossum morio, and Lasioglossum nitidulum) sampled in 12 locations along an urbanization gradient in the Ilede-France region (Paris area, France). Our objective was to test whether already recorded isotopic patterns in urban soils and plants in the Paris area would also be visible in pollinators, and to reflect on whether this would be indicative of an urban isotopic signal being transferred to pollinators. Results indicate a significant effect of urbanization on the $\delta^{13} \mathrm{C}$ and $\delta^{15} \mathrm{~N}$ for all three bee species, with enrichment for both ${ }^{13} \mathrm{C}$ and ${ }^{15} \mathrm{~N}$ linked to increased urbanization. This could be linked to an urban imprint on the diverse plants on which pollinating insects forage on in the Paris area, or to other factors linked to the physiology and foraging strategies of insects. A better understanding of the drivers influencing pollinator $\delta^{13} \mathrm{C}$ and $\delta^{15} \mathrm{~N}$ could help better understand urban biogeochemistry and trophic chains, as well as elucidate the origin of specimens and the migratory capacities of bee species, an important yet still elusive question considering the increase of habitat fragmentation.
\end{abstract}

\section{Introduction}

Urban environments have been shown to have profound, yet still poorly understood effects on key ecosystem processes such as carbon (C) and nitrogen (N) cycling (Kaye et al., 2006; Lorenz and Lal, 2009; Pouyat et al., 2009). In urban areas, $\mathrm{C}$ and $\mathrm{N}$ cycling can be influenced by numerous interacting factors including high atmospheric $\mathrm{CO}_{2}$ concentration, high levels of atmospheric $\mathrm{N}$ deposition, increased surface temperatures, pollutants, surface sealing, hydrologic changes, increased presence of non-native organisms, and different intentional management practices (McDonnell and Pickett, 1990; Kaye et al., 2006; Grimm et al., 2008; Hahs and Evans, 2015; Alberti et al., 2017). Similarly, urban habitats are known to impose several constraints to organisms (McDonnell and Hahs, 2015), but the mechanistic understanding of organisms' responses to these constraints is still lacking even for some key aspects of their ecology. For bee communities, for instance, the loss of habitat through urbanization has been shown to reduce bee abundance and richness (Fortel et al., 2014; Geslin et al., 2016a), but counter examples have also been reported (Baldock et al., 2015, 2019; Hall et al., 2017). Despite significant progress in urban ecological research over the last decades, many unknowns remain as to how urban land-use influences key ecosystem processes. This is the case for $\mathrm{C}$ and $\mathrm{N}$ cycling, as well as for key aspects of organism ecology, such as community assembly and network interactions (Carreiro and Tripler,

\footnotetext{
${ }^{*}$ Corresponding author. Institute of Ecology and Environmental Sciences - IEES Paris (UMR 7618, UPMC, CNRS, IRD, INRA, UPEC, Paris Diderot), Sorbonne Université, 4 Place Jussieu, 75005 Paris, France.

${ }^{* *}$ Corresponding author.

E-mail addresses: aleksandar.rankovic@sciencespo.fr (A. Rankovic), benoit.geslin@imbe.fr (B. Geslin).

${ }^{1}$ Both authors contributed equally to the paper.
} 
2005; Pataki et al., 2011; Geslin et al., 2013; McDonnell and MacGregor-Fors, 2016).

The study of natural abundances of $\mathrm{C}$ and $\mathrm{N}$ stable isotopes, ${ }^{13} \mathrm{C}$ and ${ }^{15} \mathrm{~N}$, can help infer mechanistic hypotheses on ecosystem processes. Stable isotopes can act as "ecological recorders" (West et al., 2006) and integrate information on the sources of elements, as well as the transformations they undergo while they cycle in ecosystems, during trophic interactions and other biogeochemical processes (e.g., Peterson and Fry, 1987; Högberg, 1997; Perkins et al., 2014; Craine et al., 2015). As such, they have already proven useful, albeit arguably still underused, tools in urban ecology (Pataki et al., 2005).

Stable isotope analyses have been used both to trace the assimilation of anthropogenic compounds in ecosystems and biological responses to urban conditions. For instance, the assimilation by urban grasses of fossil fuel $\mathrm{CO}_{2}$, strongly depleted in ${ }^{13} \mathrm{C}$ compared to background levels, has been analyzed in Paris and Los Angeles (Lichtfouse et al., 2003; Wang and Pataki, 2010). Also, nitrogen compounds produced during combustion processes tend to be enriched in the ${ }^{15} \mathrm{~N}$ isotope, and using $\delta^{15} \mathrm{~N}$ measurements, Wang and Pataki (2010) recorded spatial patterns in the $\delta^{15} \mathrm{~N}$ of annual grasses sampled in the Los Angeles basin, with grasses in the mostly urbanized areas being strongly enriched in ${ }^{15} \mathrm{~N}$ when compared to the rest of the basin. This result is consistent with several reports indicating enriched $\delta^{15} \mathrm{~N}$ values for deposited $\mathrm{N}$ in other urban environments (e.g., Ammann et al., 1999; Pearson et al., 2000; Widory, 2007).

For four tree species growing in parks of New York City, FalxaRaymond et al. (2014) report higher foliar $\delta^{13} \mathrm{C}$ (e.g., less depleted in ${ }^{13} \mathrm{C}$ ) values than in rural areas, likely reflecting reduced stomatal conductance in response to water stress (water-use efficiency - WUE strategy). In Los Angeles, Wang and Pataki (2012) found a strong relation between soil moisture and grass $\delta^{13} \mathrm{C}$ : grasses were more depleted in ${ }^{13} \mathrm{C}$ as soil moisture increased. A similar result was found for roadside trees in Kyoto by Kagotani et al. (2013), who suggest that isotopic effects linked to WUE could compensate the isotopic imprint of fossil fuel-derived $\mathrm{CO}_{2}$ on the organic matter produced by trees. In Paris, enrichment in ${ }^{13} \mathrm{C}$ and ${ }^{15} \mathrm{~N}$ has been reported for both street soils and trees, when compared to remote counterparts (Rankovic, 2016).

While data on soils and plants starts accumulating, such results are still scarce for animals. Fujita and Koike (2009) used ${ }^{13} \mathrm{C}$ and ${ }^{15} \mathrm{~N}$ analyses to follow the transport of nutrients by birds along an urbanrural transect from Yokohama to a mountainous forest-dominated landscape. Smith et al. (2019) gathered data on stable lead (Pb) isotopes in and around Vancouver to study the contamination of bees and honey by urban pollution. Taki et al. (2017) compared stable nitrogen and carbon isotope ratios in Apis cerrana populations (Asian honeybees) across several land uses over an area covering most of Japan. They found urban areas to negatively affect bee $\delta^{13} \mathrm{C}$ values and positively affect bee $\delta^{15} \mathrm{~N}$ : for $\delta^{13} \mathrm{C}$, they hypothesized a possible effect of fossil fuel $\mathrm{CO}_{2}$, while no hypothesis was clearly being put forth for $\delta^{15} \mathrm{~N}$. However, no existing study has investigated whether a visible urban effect on soil and plant $\mathrm{C}$ and $\mathrm{N}$ biogeochemistry is being transferred to the animal compartment of urban ecosystems through trophic interactions. Developing this line of investigation would increase our overall understanding of urban $\mathrm{C}$ and $\mathrm{N}$ biogeochemistry, but also help better understand urban community ecology, through, e.g., the study of food chain length, trophic structure, and even life-history traits (Brosi et al., 2009; Perkins et al., 2014).

Wild bees are good candidates to explore such questions. As they are strictly phytophagous organisms at all stages of their life cycle, the $\delta^{13} \mathrm{C}$ and $\delta^{15} \mathrm{~N}$ values of adult individuals should reflect the $\delta^{13} \mathrm{C}$ and $\delta^{15} \mathrm{~N}$ of flower-derived (nectar and pollen) food that they received as larvae, and the $\delta^{13} \mathrm{C}$ and $\delta^{15} \mathrm{~N}$ of flower-derived resources that they forage on as adults. The $\delta^{13} \mathrm{C}$ and $\delta^{15} \mathrm{~N}$ of individual wild pollinating insects should closely reflect the $\delta^{13} \mathrm{C}$ and $\delta^{15} \mathrm{~N}$ of their plant diet, notwithstanding other factors (e.g., physiological) that can have more moderate effects (Taki et al., 2017). Furthermore, urban environments are known to strongly influence insect pollinator communities (Deguines et al., 2016; Geslin et al., 2016a), but it is still hard to study how urban pollinators forage and move inside urban landscapes. This is even more difficult since radio-tracking tools work for larger species, while most insects are very small in size and have limited dispersal abilities. Isotopic data on urban pollinators can thus help explore aspects of their life-history traits that are not easily accessible to investigators.

Here, we report ${ }^{13} \mathrm{C}$ and ${ }^{15} \mathrm{~N}$ natural abundance values measured on three pollinating species of wild bees (Lasioglossum laticeps, Lasioglossum morio, and Lasioglossum nitidulum) sampled along an urbanization gradient in the Ile-de-France region (Paris area, France). Our objective was to test whether already recorded isotopic patterns in urban soils and plants in the Paris area would also be visible in pollinators, and to reflect on whether this would be indicative of an urban isotopic signal transfer to pollinators. Our hypothesis was that if the soil and plant $\delta^{13} \mathrm{C}$ and $\delta^{15} \mathrm{~N}$ patterns reported in the Paris area (Rankovic, 2016) were transferred to pollinators, then similar changes should be observed in insect $\delta^{13} \mathrm{C}$ and $\delta^{15} \mathrm{~N}$ with increasing levels of urbanization, represented by the impervious surface proportion in the landscape (Geslin et al., 2016a). To discuss the likelihood of different hypotheses that could explain these patterns, we also used flora inventories data to test for species composition changes that could affect insect $\delta^{13} \mathrm{C}$ and $\delta^{15} \mathrm{~N}$ values: we especially looked for the presence of C4 (and CAM) and Nfixating plant species, which could respectively enrich insects in ${ }^{13} \mathrm{C}$ compared to C3 species and bring their $\delta^{15} \mathrm{~N}$ closer to $0 \%$ compared to non-N fixating species (Peterson and Fry, 1987; Högberg, 1997).

\section{Materials and methods}

\subsection{Study sites}

Our study was located in Paris and its region (Ile-de-France, France), the most populated region of France with more than 11 million residents (INSEE, 2013). We chose twelve sites located at least $1 \mathrm{~km}$ from each other according to their proportion of impervious surfaces within a $500 \mathrm{~m}$ radius, in order to cover a gradient of urbanization (Fig. 1). Impervious surfaces coverage, which expresses the proportion of an area covered by buildings, parking, pavements and roads (Marzluff, 2005; Sattler et al., 2010; Liu et al., 2014), has been acknowledged as a key parameter to quantify the urbanization level (Arnold and Gibbons, 1996; Mckinney, 2006, 2008) and is increasingly used in studies linking urbanization and bee communities (Ahrné et al., 2009; BanaszakCibicka and Żmihorski, 2012; Geslin et al., 2013, 2016a; Fortel et al., 2014). Among our 12 sites, the proportion of impervious surfaces ranged from 0.06 to $64.31 \%$ (mean $=25.25 \% \pm 24.58$ ) with the most urbanized site being located in the center of Paris (Table 1). Three sites were dominated by agricultural landscapes, Grignon (48 $50^{\prime} 29.60^{\prime \prime}$ / $\left.1^{\circ} 56^{\prime} 24.92^{\prime \prime}\right)$, Ambésis (48 43'44.36"/ $\left.{ }^{\circ} 58^{\prime} 22.54^{\prime \prime}\right)$ and Bezanleu $\left(48^{\circ} 17^{\prime} 07.23^{\prime \prime} / 2^{\circ} 48^{\prime} 45.24^{\prime \prime}\right)$. Three sites were dominated by semi-naturals habitats, St Lambert $\left(48^{\circ} 44^{\prime} 16.28^{\prime \prime} / 2^{\circ} 01^{\prime} 05.66^{\prime \prime}\right)$, Foljuif $\left(48^{\circ} 16^{\prime} 54.84^{\prime \prime} / 2^{\circ} 39^{\prime} 58.88^{\prime \prime}\right)$, and Versailles I (48 $48^{\prime} 20.74^{\prime \prime} /$ $\left.2^{\circ} 05^{\prime} 39.14^{\prime \prime}\right)$. Three sites were dominated by peri-urban landscapes: two sites were located in the town hall garden of small towns, Bonnelles ( $\left.48^{\circ} 37^{\prime} 07.21^{\prime \prime} / 2^{\circ} 01^{\prime} 43.59^{\prime \prime}\right)$ and Nemours (48 $\left.15^{\prime} 54.70^{\prime \prime} / 2^{\circ} 41^{\prime} 09.80^{\prime \prime}\right)$, and one site in the graveyard of Versailles; Versailles II $\left(48^{\circ} 47^{\prime} 27.00^{\prime \prime}\right.$ / $\left.2^{\circ} 08^{\prime} 21.20^{\prime \prime}\right)$. Finally, three sites were located in densely urbanized landscapes in Paris, in public parks: Paris I (48 50'41.93" $\left./ 2^{\circ} 20^{\prime} 18.94^{\prime \prime}\right)$, Paris II $\left(48^{\circ} 50^{\prime} 38.13^{\prime \prime} / 2^{\circ} 21^{\prime} 40.54^{\prime \prime}\right)$, and Paris III $\left(48^{\circ} 49^{\prime} 13.90^{\prime \prime}\right.$ / $\left.2^{\circ} 19^{\prime} 52.03^{\prime \prime}\right)$.

At each site, we worked on a $500 \mathrm{~m}$ radius because it encompasses the estimated mean flight distances for most species of wild bees (Gathmann and Tscharntke, 2002; Araújo et al., 2004; Zurbuchen et al., 2010), and it is widely used in studies linking bee assemblages and landscape composition (Holzschuh et al., 2008; Somme et al., 2014), especially within urbanization contexts (Ahrné et al., 2009; BanaszakCibicka and Żmihorski, 2012; Geslin et al., 2013, 2016a; Fortel et al., 


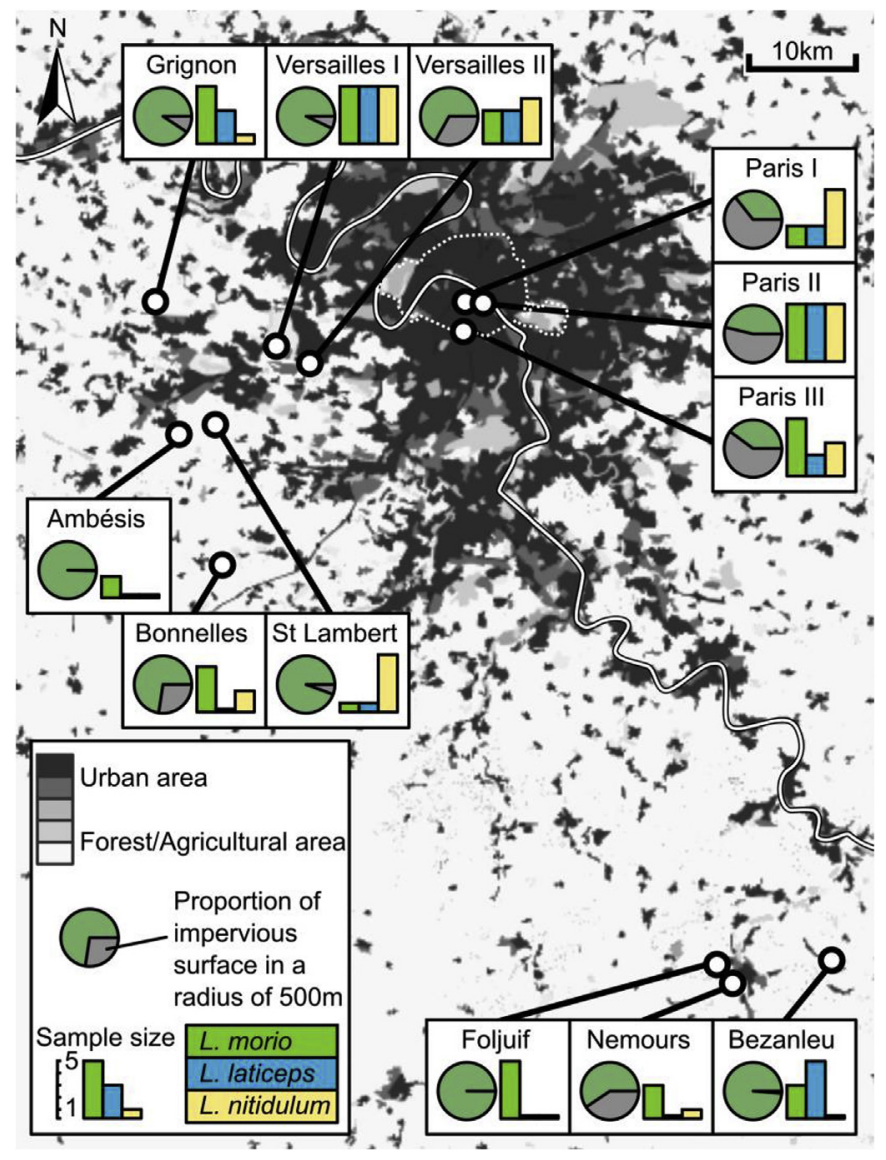

Fig. 1. Locations of the 12 capture sites in the study area. The proportion of impervious surfaces for each site is represented with a pie chart and colored in grey in the chart - the green color corresponds to other land covers. Barplots illustrate the sample effort for each bee species at each site. (For interpretation of the references to colour in this figure legend, the reader is referred to the web version of this article.)

2014).

\subsection{Bee sampling}

We captured bee individuals during the spring and summer of 2011 using colored pan traps. These traps are bowls (radius $=7.25 \mathrm{~cm}$, depth $=5 \mathrm{~cm}$ ) painted with blue, white, or yellow UV-reflecting paints (Westphal et al., 2008). A set of three pan traps (one of each color) was installed in each experimental site. Each pan trap was mounted on a wooden pole, filled with $400 \mathrm{ml}$ of water mixed with a few drops of detergent (surfactant, dishwashing liquid, Colgate-Palmolive Company, New York, NY, USA, same bottle used for all collection sites), and laid in the field for $24 \mathrm{~h}$. Those traps attract bees as they mimic flowers, and bees drown themselves in the liquid.

Once captured, insects were stored in $70 \%$ ethanol before being rinsed, dried, mounted, and identified by professional taxonomists (acknowledgement). Ethanol is a good preservative for insects, and it does not appear to affect their stable isotopic ratios (Hobson et al.,
1997; Dammhahn et al., 2015). The detailed list of wild bees captured has been published in Geslin et al. (2016a, b). Among those captures, we selected 3 species based on their abundance in all twelve sites (Table 1): Lasioglossum laticeps (Schenck, 1868), Lasioglossum morio (Fabricius, 1793) and Lasioglossum nitidulum (Fabricius, 1804). They are all soil nesters and polylectic (generalists in their diet breadth; Michener, 2007). Lasioglossum laticeps and L. morio exhibit a gregarious social behavior (females dig nests close to each other) whereas individuals of L. nitidulum are solitary (Michener, 2007; Lanner et al., 2020).

\subsection{Composition of the local entomophilous flowering community}

At each of the 12 experimental sites, we also estimated the composition of plant communities. To do so, we sampled five $2 \times 5 \mathrm{~m}^{2}$ plots located at increasing distances of the pan traps. The first of the five plots was contiguous to the three pan traps. The other four plots were placed at 50,100,150, and $200 \mathrm{~m}$ in a randomly chosen direction (north, east, south or west). Plots were divided into 10 cells of $1 \mathrm{~m}^{2}$, and the presence/absence of each plant species for each cell was noted. By pooling the five plots at each site, we estimated the abundance of each flowering plant species with an index ranging from 1 to 50 . We focused on entomophilous flowering plants species given their importance to bees, which were identified to the species level. We estimated the abundance of Fabaceae species, as members of the Fabaceae family can fix atmospheric $\mathrm{N}_{2}$ and their $\delta^{15} \mathrm{~N}$ tends to be closer to $0 \%$ compared to other species growing in the same surroundings (Högberg, 1997). We also looked for C4 and CAM species but we only found C3 species among the entomophilous plant species identified. Its nevertheless worth noting that a corn field (anemophilous, C4) was present around one of the agriculture-dominated sites (Grignon). We used TAXREF (v12.0), the French Taxonomic Reference for the flora and fauna of metropolitan France and overseas (http://inpn.mnhn.fr/ telechargement/referentielEspece/referentielTaxo). The list of species is available in Supplementary Material 1.

\section{4. $C$ and $N$ contents and isotope ratios}

All sampled individuals were analyzed for $\delta^{13} \mathrm{C}$ and $\delta^{15} \mathrm{~N}$. Insects were lyophilized for $48 \mathrm{~h}$ and stored in a desiccator until analysis. The whole body of each individual was then ground with pestle and mortar, and about $1 \mathrm{mg}$ of powdered sample was weighed in a tin capsule and analyzed by EA-IRMS (vario Pyro cube, Elementar, Hanau, Germany, coupled with an IsoPrime, Gvi, Stockport, UK) (e.g., Taki et al., 2017).

For isotopic values, results are expressed using the usual delta notation that allows expressing the content in ${ }^{13} \mathrm{C}$ or ${ }^{15} \mathrm{~N}$ as the relative difference between the isotopic ratio of the sample and a standard, calculated as:

$\delta(\%)=[($ Rsample - Rstandard $) /$ Rstandard $] * 1000$

where Rsample is the isotope ratio $\left({ }^{13} \mathrm{C} /{ }^{12} \mathrm{C}\right.$ and ${ }^{15} \mathrm{~N} /{ }^{14} \mathrm{~N}$ for $\mathrm{C}$ and $\mathrm{N}$, respectively) of the sample and Rstandard the isotope ratio of the standard. $\mathrm{C}$ and $\mathrm{N}$ isotopic ratios are expressed with respect to the $\mathrm{V}$ PDB (Vienna Pee Dee Belemnita, Craig, 1957) and to air nitrogen (Mariotti, 1983; Mariotti et al., 1984), respectively. The measured values are available in Supplementary Material 2.

Table 1

Impervious surface (in \%) at the twelve study sites, and number of sampled individuals for the three bee species.

\begin{tabular}{|c|c|c|c|c|c|c|c|c|c|c|c|c|}
\hline & Foljuif & Ambésis & Bezanleu & St Lambert & Versailles I & Grignon & Bonnelles & Versailles II & Nemours & Paris II & Paris III & Paris I \\
\hline Impervious surfaces & 0.061 & 0.5 & 1.33 & 5.55 & 7.01 & 9.33 & 27.38 & 33.09 & 40.57 & 53.78 & 60.12 & 64.31 \\
\hline L. laticeps & 0 & 0 & 5 & 1 & 5 & 3 & 0 & 3 & 0 & 5 & 2 & 2 \\
\hline L. morio & 5 & 2 & 3 & 1 & 5 & 5 & 4 & 3 & 3 & 5 & 5 & 2 \\
\hline L. nitidulum & 0 & 0 & 0 & 5 & 5 & 1 & 4 & 4 & 1 & 5 & 3 & 5 \\
\hline
\end{tabular}


Table 2

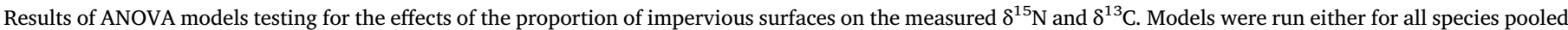

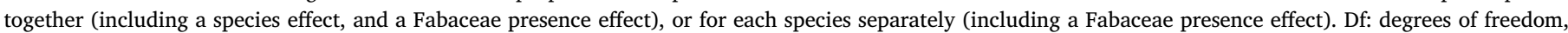
significance levels: ***: $\mathrm{P}<0.001 ; * * \mathrm{P}<0.01$; $: \mathrm{P}<0.05)$.

\begin{tabular}{|c|c|c|c|c|c|c|c|}
\hline & & Factor & Df & Mean Square & F Value & P-value & $*$ \\
\hline \multirow[t]{5}{*}{ All species } & $\delta^{15} \mathrm{~N}$ & Species & 2 & 44.72 & 7.80 & $<0.001$ & $* * *$ \\
\hline & & Fabaceae & 1 & 34.43 & 6.01 & 0.016 & $*$ \\
\hline & & Impervious surfaces & 1 & 273.77 & 47.76 & $<0.001$ & $* * *$ \\
\hline & $\delta^{13} \mathrm{C}$ & Species & 2 & 7.03 & 5.62 & 0.004 & $* *$ \\
\hline & & Impervious surfaces & 1 & 27.28 & 21.81 & $<0.001$ & $* * *$ \\
\hline \multirow[t]{3}{*}{ Lasioglossum laticeps } & $\delta^{15} \mathrm{~N}$ & Fabaceae & 1 & 48.02 & 8.95 & 0.006 & $* *$ \\
\hline & & Impervious surfaces & 1 & 137.17 & 25.58 & $<0.001$ & $* * *$ \\
\hline & $\delta^{13} \mathrm{C}$ & Impervious surfaces & 1 & 21.95 & 21.98 & $<0.001$ & $* * *$ \\
\hline \multirow[t]{3}{*}{ Lasioglossum morio } & $\delta^{15} \mathrm{~N}$ & Fabaceae & 1 & 1.30 & 0.20 & 0.65 & \\
\hline & & Impervious surfaces & 1 & 121.23 & 18.86 & $<0.001$ & $* * *$ \\
\hline & $\delta^{13} \mathrm{C}$ & Impervious surfaces & 1 & 9.5 & 9.72 & 0.013 & * \\
\hline \multirow[t]{3}{*}{ Lasioglossum nitidulum } & $\delta^{15} \mathrm{~N}$ & Fabaceae & 1 & 7.75 & 1.62 & 0.21 & \\
\hline & & Impervious surfaces & 1 & 25.08 & 5.24 & 0.028 & * \\
\hline & $\delta^{13} \mathrm{C}$ & Impervious surfaces & 1 & 1.91 & 1.72 & 0.19 & \\
\hline
\end{tabular}

\subsection{Data analysis}

Statistical analyses were performed with the $R$ software ( $R$ Development Core Team, 2013). The effects of the proportion of impervious surface on the measured bee $\delta^{13} \mathrm{C}$ and $\delta^{15} \mathrm{~N}$ was analyzed with a linear model. Models were run either for each species separately or for all three species, in the latter case including species as an additional explanatory factor. The p-values were obtained with analysis of variance (Anova) using a Fisher test. We systematically checked for normality of residuals and data were log transformed in case of non-normal residuals. As explained above, since Fabaceae plants may affect $\delta^{15} \mathrm{~N}$, we included this effect in the $\delta^{15} \mathrm{~N}$ models.

\section{Results}

We collected 45 individuals of $L$. morio, 34 of $L$. nitidulum and 28 of L. laticeps along our urbanization gradient (Table 1 ).

Regarding the $\delta^{13} \mathrm{C}$ of bees, an increase was observed for all three bee species with the increase of impervious surfaces proportion around sites $(\mathrm{F}=22.46, \mathrm{P}<0.001)$ (Table 2, Fig. 2). There was no significant effect of the interaction between species and the proportion of impervious surface. A significant increase of $\delta^{13} \mathrm{C}$ was observed with the proportion of impervious surfaces for individuals of $L$. morio $(\mathrm{F}=9.72$, $\mathrm{P}=0.013)$ and $L$. laticeps $(\mathrm{F}=21.98, \mathrm{P}<0.001)$, but this relation was however not significant for L. nitidulum $(\mathrm{F}=1.72, \mathrm{P}=0.19$; Table 2, Fig. 2). For the three sites that had respectively the smallest (average of $0.6 \%$ ) and highest amount of impervious surface (average of $59.3 \%$ ), the average $\delta^{13} \mathrm{C}$ values were respectively $-25.9 \%$ and $24.1 \%$, a difference of $1.8 \%$.

For the $\delta^{15} \mathrm{~N}$ values, an increase was observed for the three bee species with the increasing proportion of impervious surfaces around capture sites $(\mathrm{F}=47.76, \mathrm{P}<0.001)$. Species per species, this was significant for the three species: $L$. morio $(\mathrm{F}=18.86, \mathrm{P}<0.001) ; L$. nitidulum $(\mathrm{F}=5.24, \mathrm{P}=0.028)$ and $L$. laticeps $(\mathrm{F}=25.58, \mathrm{P}<0.001)$ (Table 2, Fig. 3). There was no significant effect of the interaction between species and the proportion of impervious surface. The abundance of Fabaceae species had a significant negative influence on the $\delta^{15} \mathrm{~N}$ of the three bee species grouped together $(\mathrm{F}=6.22, \mathrm{P}=0.016)$ and on the $\delta^{15} \mathrm{~N}$ of $L$. laticeps $(\mathrm{F}=8.95, \mathrm{P}=0.006$ ); no significant effect of Fabaceae abundance was found for L. nitidulum and L. morio (Table 2, Fig. 3). For the three sites that had respectively the smallest (average of
$0.6 \%$ ) and highest amount of impervious surface (average of 59.3\%), the average $\delta^{15} \mathrm{~N}$ values were respectively $1.6 \%$ and $6.2 \%$, a difference of $4.6 \%$.

\section{Discussion}

\subsection{A significant effect of urbanization on the $\delta^{13} C$ and $\delta^{15} N$ of wild bees}

Our results show a significant effect of urbanization on the stable isotope content of bees. Both the $\delta^{13} \mathrm{C}$ and the $\delta^{15} \mathrm{~N}$ increased with the proportion of impervious surfaces in a $500 \mathrm{~m}$ radius around specimens' collection point. The variation in stable isotope abundance explained by the proportion of impervious surfaces was even higher than that explained by the difference between species (3.9 and 6.1 times higher for $\delta^{13} \mathrm{C}$ and $\delta^{15} \mathrm{~N}$, respectively). Isotopic response to the urbanization gradient slightly varied among species (Figs. 2 and 3), with a stronger effect on L. laticeps and a weaker effect on $L$. nitidulum. However, this difference was not significant in the analyses (as revealed by the nonsignificant interaction term either for the $\delta^{13} \mathrm{C}$ or the $\delta^{15} \mathrm{~N}$ ). The urban environment thus seems to induce similar effects on the three $\mathrm{La}$ sioglossum species we studied and leads to an increase in their $\delta^{13} \mathrm{C}$ and $\delta^{15} \mathrm{~N}$.

Furthermore, while samples were collected in the same region and within the same season, the difference in values observed at the extremes of the gradient were quantitatively important for both ${ }^{13} \mathrm{C}$ and ${ }^{15} \mathrm{~N}$. For ${ }^{13} \mathrm{C}$, the difference between the less and most urbanized sites, was of the order of magnitude $(1.8 \%$ ) of the differences found between rural and urban populations of kit foxes (Newsome et al., 2010) and Tetramorium ants (Penick Clint et al., 2015), and between human populations in Europe and the United States (Bol and Pflieger, 2002). For ${ }^{15} \mathrm{~N}$, the difference is also high $(4.6 \%)$ ): it is of the same order of magnitude, for instance, as the experimental values reported in the literature for trophic level changes inside plant-invertebrate food chains spanning four trophic levels (maximum $\Delta$ of $4.81 \%$ ) (Perkins et al., 2014). For the same bee species, living in the same region, urbanization was thus related to marked patterns for $\delta^{13} \mathrm{C}$ and $\delta^{15} \mathrm{~N}$ values, and we discuss possible causes below. 


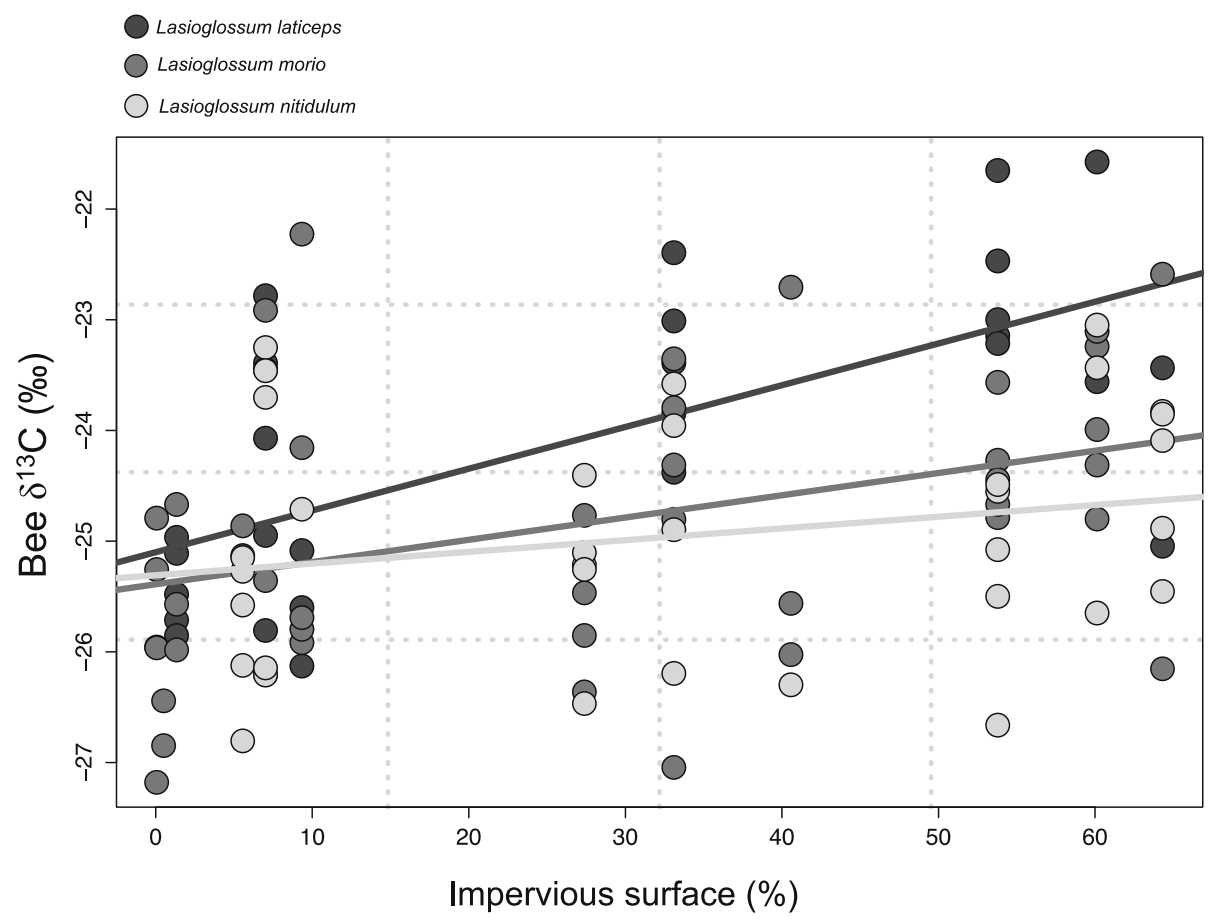

Fig. 2. Bee $\delta^{13} \mathrm{C}$ for all three studied species following the percentage of impervious surface around capture sites.

\subsection{Urban environmental factors that could explain $\delta^{13} \mathrm{C}$ and $\delta^{15} \mathrm{~N}$ patterns}

The increase of bee $\delta^{13} \mathrm{C}$ following the increase of impervious surfaces could be reflecting the effects of urban conditions on plants. As recalled in the introduction, the assimilation of fossil fuel $\mathrm{CO}_{2}$, strongly depleted in ${ }^{13} \mathrm{C}$ compared to background levels, has been reported for grasses in Paris and Los Angeles (Lichtfouse et al., 2003; Wang and Pataki, 2010). However, our results indicate an opposite trend, of ${ }^{13} \mathrm{C}$ enrichment rather than depletion with increased urbanization. This could reflect a plant response to increased water scarcity with the increasing amount of impervious surfaces, which leads to less water infiltration in soils and an increased urban heat island effect (increased temperature). This was observed for grass species in the Los Angeles area (Wang and Pataki, 2010), and tree species in Kyoto and New York City (Kagotani et al., 2013; Falxa-Raymond et al., 2014). Kagotani et al. (2013) explicitly proposed that isotopic effects linked to WUE could compensate the isotopic imprint of fossil fuel-derived $\mathrm{CO}_{2}$ on the organic matter produced by trees. In Paris, Rankovic (2016) found that urban conditions result in an enrichment of soil and tree $\delta^{13} \mathrm{C}$ and

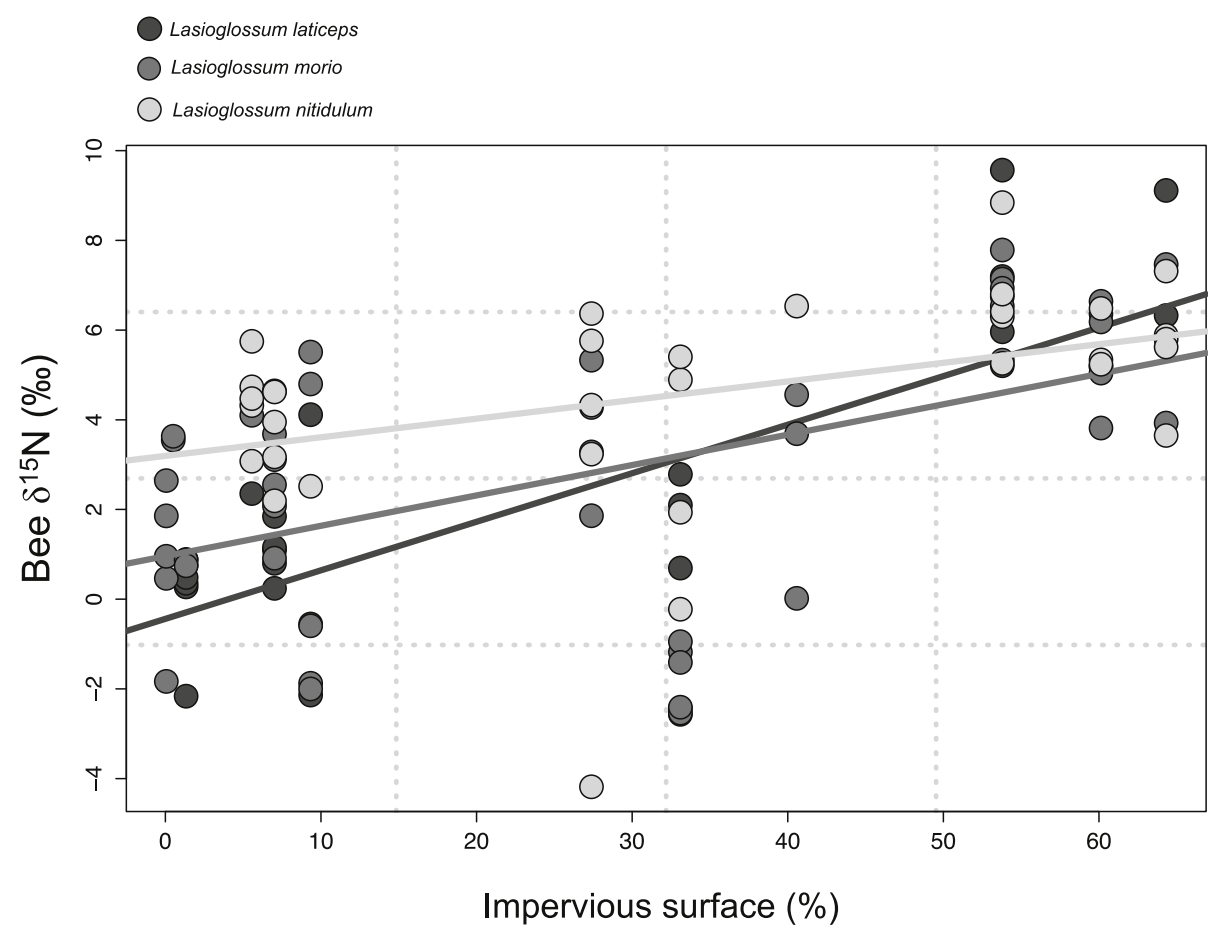

Fig. 3. Bee $\delta^{15} \mathrm{~N}$ for all three studied species following the percentage of impervious surface around capture sites. 
hypothesized that it was linked to the response of trees to urban drought (documented by David et al., 2018) and the subsequent transfer of ${ }^{13} \mathrm{C}$-enriched tree root organic matter to soil. The urbanization effects on $\delta^{13} \mathrm{C}$ observed for wild bees are of a similar order of magnitude as the hypothesized drought effect reported for plants. If this urban climate-related effect on plant $\delta^{13} \mathrm{C}$ was widespread across urban landscapes, the observed pattern on bee $\delta^{13} \mathrm{C}$ could be explained by a transfer of this signal from urban plants to their consumers. Urban areas also seem to favor plants with C4 photosynthesis (Duffy and Chown, 2016). This specific photosynthesis pathway has an impact on the $\delta^{13} \mathrm{C}$ of plants, which reflects on their nectar consumers (Peterson and Fry, 1987; Proctor et al., 1996). In our case, no C4 plants were found in the plant communities of collection sites, thus excluding this hypothesis to explain the observed pattern in bee $\delta^{13} \mathrm{C}$.

The urbanization effect observed on $\delta^{15} \mathrm{~N}$ could also be explained by urban biogeochemical factors. Wang and Pataki (2010) report that annual grasses in the mostly urbanized areas of the Los Angeles basin were strongly enriched in ${ }^{15} \mathrm{~N}$ when compared to the rest of the basin. This result is consistent with several reports indicating enriched $\delta^{15} \mathrm{~N}$ values for deposited $\mathrm{N}$ in other urban environments (e.g., Ammann et al., 1999; Pearson et al., 2000; Widory, 2007). In Paris, Widory (2007) found that atmospheric particulate $\mathrm{N}$ (ammonium and nitrate) had a $\delta^{15} \mathrm{~N}$ as high as $10 \%$ on a yearly average. Direct measurements from vehicle exhaust yielded a $\delta^{15} \mathrm{~N}$ for particulate $\mathrm{N}$ of $3.9-5.6 \%$ (Widory, 2007). In Paris, Rankovic (2016) reported an enrichment (agerelated enrichment for urban ecosystems, and also compared to periurban sites under the same species) of street soil and tree $\delta^{15} \mathrm{~N}$ (total soil $\mathrm{N}$ and foliar $\mathrm{N}$ ) values and suggested that it was linked to the entrance of strongly ${ }^{15} \mathrm{~N}$-enriched urban reactive $\mathrm{N}$ in soil-tree systems and its subsequent transformations in soils (notably, high rates of nitrification and denitrification). The difference between tree foliar $\delta^{15} \mathrm{~N}$ measured in remote areas and in streets was of about $5 \%$, with urban values being close to $7 \%$, which is similar to the orders of magnitude observed here for pollinators. As for $\delta^{13} \mathrm{C}$, if urbanization biogeochemical effects leading to increased plant $\delta^{15} \mathrm{~N}$ are widespread, it could be reflected in wild pollinator $\delta^{15} \mathrm{~N}$, as observed here.

\subsection{Factors linked to bee physiology and foraging that could explain $\delta^{13} \mathrm{C}$ and $\delta^{15} N$ patterns}

Besides plant-insect transmission, other factors could also explain the patterns we observed, more related to animal physiology and foraging behavior.

${ }^{13} \mathrm{C}$-enriched sugar sources may exist in urban areas due to a direct anthropogenic effect: human food waste (Newsome et al., 2010; Penick Clint et al., 2015). Like many other insects, honeybees are known to forage on food wastes rich in sugars from corn or cane origins. Since human wastes may be more abundant in urban areas, this effect could impact the $\delta^{13} \mathrm{C}$ of animals consuming these food sources. Such an effect of food wastes in urban areas on $\delta^{13} \mathrm{C}$ was observed on ants in North America but could not be shown on honeybees (Penick Clint et al., 2015, Penick et al., 2016). In the latter case, a bias could be induced by the beekeepers provisioning their hives with corn syrup both in urban and rural areas (Penick et al., 2016). Such provisioning does not occur with the three non-managed bee species studied here. We are not aware of any observation of these small wild bees foraging on food waste. However, although unlikely, we cannot entirely exclude this hypothesis to explain the patterns of $\delta^{13} \mathrm{C}$ highlighted in this study. As most carbohydrates consumed by bees do not contain $\mathrm{N}$, potential foraging on food waste for sugar should have little effect on bee $\delta^{15} \mathrm{~N}$.

Hydric stress may also modify animal metabolism, inducing a further increase in the $\delta^{15} \mathrm{~N}$ (Ambrose and DeNiro, 1986). Protein catabolism under food stress has also been related to increase in $\delta^{15} \mathrm{~N}$ (Hobson, 1999). Hence, hydric stress could also have a direct change in the metabolism of bees, and food stress could also induce such a pattern in their $\delta^{15} \mathrm{~N}$.
In addition, plant community composition, hence bees' diet composition, varies between urban and non-urban areas. In our case, both plant species richness and amount of nitrogen fixing Fabaceae were negatively correlated with the proportion of impervious surface (data not shown). However, the Fabaceae abundance was included in our models. Furthermore, in other models, not shown, we tested the effect of plant diversity overall, and did not find and effect that was distinguishable from the effect of Fabaceae alone. This low impact of plant species composition, and especially the abundance of Fabaceae, on the $\delta^{15} \mathrm{~N}$ of bees, could also be influenced by plant choices of the bees studied here: most Fabaceae are pollinated by long-tongue bees, able to reach the nectar at the bottom of their long flowers. Even if they are polylectic, these Lasioglossum bees are both small and with a short tongue, hence they might not be able to forage on many Fabaceae plants (Pellissier et al., 2012). The presence of a corn field around one rural site might possibly have influenced the bee $\delta^{13} \mathrm{C}$ (leading to an enrichment of bees from this rural site, compared to sites without corn fields), since bee can occasionally forage on anemophilous plants, seeking for pollen (Saunders, 2018). However, only one capture site was concerned, and a potential effect of corn would have weakened the observed effect of urbanization, rather than causing the reported patterns. The results nonetheless highlight that plant composition, hence food resources, changed throughout the gradient, with potential effects on isotope ratios, albeit surpassed by other factors linked to urbanization.

\section{Conclusion}

A strong effect of the increase of impervious surfaces was observed for the $\delta^{13} \mathrm{C}$ and $\delta^{15} \mathrm{~N}$ of three species of wild bees in the Paris area. This could be linked to an urban imprint on the diverse plants on which pollinating insects forage on in the Paris area, or other factors linked to the physiology and foraging strategies of insects (e.g., sugars in human food). In the first case, this would imply that an urban isotopic signal is transmitted from primary producers to their animal consumers and can thus further imprint urban trophic networks. In the second case, this would have implications for our understanding of the physiological stresses imposed by urban environments on pollinating insects, and potential changes in foraging strategies as a potential response to urban constraints and opportunities. To further discriminate among the processes that could explain the observed patterns, further studies could, alongside isotopic data on pollinators, also sample plants and other potential food sources at the sampling sites. This would help improve the understanding of urban biogeochemistry and trophic chains. A better understanding of the factors influencing pollinator $\delta^{13} \mathrm{C}$ and $\delta^{15} \mathrm{~N}$ could also help elucidate the origin of specimens and the migratory capacities of bee species, an important yet still elusive question considering the increase of habitat fragmentation.

\section{Author contributions}

Benoit Geslin \& Aleksandar Rankovic conceived the study, were involved in laboratory and statistical analyses, and wrote the paper.

Adrien Perrard performed statistical analyses and graphical work.

Benout Geslin \& Isabelle Dajoz realised the field work.

Anne Barbillon \& Veronique Vaury realised the laboratory analyses. Luc Abbadie help in conceiving the study and writing the paper. All authors corrected and proofread the manuscript.

\section{Acknowledgements}

We are very grateful to Eric Dufrêne, Robert Fonfria, Serge Gadoum, David Genoud, Alain Pauly, Gilles Mahé, and Erwin Scheuchl for their help with the bee identifications. We thank Yann Rantier for helping with the GIS analyses and Floriane Flacher, Morgane Folschweiller, Beatriz Decencière, Jocelyne Roman, Gaëlle Fras, Alice Khamphone, 
and Caroline Chassignet for helping with the data collection. We thank Denis Michez, Boris Leroy, and Violette Le Féon for useful discussions. This work was supported by a grant from Région Ile-de-France through the DIM Astréa (Grant number: ASTREA 2009-01-22; http://www.dimastrea.fr/) and R2DS (http://www.r2ds-ile-de-france.com) programs, as well as by Université Sorbonne Paris Cité ("Politics of the Earth in the Anthropocene" program). This work was also supported by the French National Research Agency under the Investissements d'avenir programme (ANR-10-LABX-14-01). We warmly thank the two anonymous reviewers whose comments helped us improve the manuscript.

\section{References}

Alberti, M., Correa, C., Marzluff, J.M., Hendry, A.P., Palkovacs, E.P., Gotanda, K.M.,

Zhou, Y., 2017. Global urban signatures of phenotypic change in animal and plant populations. Proc. Natl. Acad. Sci. Unit. States Am. 114, 8951-8956. https://doi.org/ 10.1073/pnas.1606034114.

Ammann, M., Siegwolf, R., Pichlmayer, F., Suter, M., Saurer, M., Brunold, C., 1999. Estimating the uptake of traffic-derived $\mathrm{NO}_{2}$ from ${ }^{15} \mathrm{~N}$ abundance in Norway spruce needles. Oecologia 118, 124-131.

Ambrose, S.H., DeNiro, M.J., 1986. The isotopic ecology of East African mammals. Oecologia 69, 395-406.

Ahrné, K., Bengtsson, J., Elmqvist, T., 2009. Bumble bees (Bombus spp) along a gradient of increasing urbanization. PloS One 4 (5), e5574. https://doi.org/10.1371/journal. pone.0005574.

Araújo, E.D., Costa, M., Chaud-Netto, J., Fowler, H.G., 2004. Body size and flight distance in stingless bees (Hymenoptera: Meliponini): inference of flight range and possible ecological implications. Braz. J. Biol. Rev. Bras. Biol. 64, 563-568. https://doi.org/ 10.1590/S1519-69842004000400003.

Arnold, Chester L., Gibbons, C James, 1996. Impervious surface coverage: the emergence of a key environmental indicator. J. Am. Plann. Assoc. 62, 243-258.

Baldock, K.C.R., Goddard, M.A., Hicks, D.M., Kunin, E., Mitschunas, N., Osgathorpe, L.M., Memmott, J., 2015. Where is the UK's pollinator biodiversity? The importance of urban areas for flower- visiting insects. Proc. Roy. Soc. Biol. Sci. 282, 20142849. https://doi.org/10.1098/rspb.2014.2849.

Baldock, K.C.R., Goddard, M.A., Hicks, D.M., Kunin, W.E., Mitschunas, N., Morse, H. Memmott, J., 2019. A systems approach reveals urban pollinator hotspots and conservation opportunities. Nat. Ecol. Evol. https://doi.org/10.1038/s41559-0180769-y.

Banaszak-Cibicka, W., Żmihorski, M., 2012. Wild bees along an urban gradient: winners and losers. J. Insect Conserv. 16, 331-343. https://doi.org/10.1007/s10841-011 9419-2.

Bol, R., Pflieger, C., 2002. Stable isotope $\left({ }^{13} \mathrm{C},{ }^{15} \mathrm{~N}\right.$ and $\left.{ }^{34} \mathrm{~S}\right)$ analysis of the hair of modern humans and their domestic animals. Rapid Commun. Mass Spectrom. 16, 2195-2200.

Brosi, B.J., Daily, G.C., Chamberlain, C.P., Mills, M., 2009. Detecting changes in habitatscale bee foraging in a tropical fragmented landscape using stable isotopes. For. Ecol. Manag. 258, 1846-1855. https://doi.org/10.1016/j.foreco.2009.02.027.

Carreiro, M.M., Tripler, C.E., 2005. Forest remnants along urban-rural gradients: examining their potential for global change research. Ecosystems 8, 568-582.

Craine, J.M., Towne, E.G., Miller, M., Fierer, N., 2015. Climatic warming and the future of bison as grazers. Sci. Rep. 5, 16738. https://doi.org/10.1038/srep16738.

Craig, H., 1957. Isotopic standards for mass spectrometric analysis of carbon dioxide. Geochem. Cosmochim. Acta 12, 113-140.

David, A.A.J., Boura, A., Lata, J.C., Rankovic, A., Kraepiel, Y., Charlot, C., Barot, S., Abbadie, L., Ngao, J., 2018. Street trees in Paris are sensitive to spring and autumn precipitation and recent climate changes. Urban Ecosyst. 21, 133-145. https://doi. org/10.1007/s11252-017-0704-z.

Dammhahn, M., Rakotondramanana, C.F., Goodman, S.M., 2015. Coexistence of morphologically similar bats (Vespertilionidae) on Madagascar: stable isotopes reveal fine-grained niche differentiation among cryptic species. J. Trop. Ecol. 31 (2), 153-164. https://doi.org/10.1017/S0266467414000741.

Deguines, N., Julliard, R., De Flores, M., Fontaine, C., 2016. Functional homogenization of flower visitor communities with urbanization. Ecol. Evol. 6, 1967-1976.

Duffy, G.A., Chown, S.L., 2016. Urban warming favours C4 plants in temperate European cities. J. Ecol. 104, 1618-1626.

Falxa-Raymond, N., Palmer, M.I., McPhearson, T., Griffin, K.L., 2014. Foliar nitrogen characteristics of four tree species planted in New York City forest restoration sites. Urban Ecosyst. 17, 807-824.

Fortel, L., Henry, M., Guilbaud, L., Guirao, A.L., Kuhlmann, M., Mouret, H., Vaissière, B.E., 2014. Decreasing abundance, increasing diversity and changing structure of the wild bee community (Hymenoptera: Anthophila) along an urbanization gradient. PloS One 9 (8), e104679. https://doi.org/10.1371/journal.pone.0104679.

Fujita, M., Koike, F., 2009. Landscape effects on ecosystems: birds as active vectors of nutrient transport to fragmented urban forests versus forest-dominated landscapes. Ecosystems 12, 391-400. https://doi.org/10.1007/s10021-009-9230-z.
Gathmann, A., Tscharntke, T., 2002. Foraging ranges of solitary bees. J. Anim. Ecol. 71, 757-764. Retrieved from. http://onlinelibrary.wiley.com/doi/10.1046/j.13652656.2002.00641.x/full.

Geslin, B., Gauzens, B., Thebault, E., Dajoz, I., 2013. Plant pollinator networks along a gradient of urbanisation. PloS One 8, e63421. https://doi.org/10.1371/journal.pone. 0063421.

Geslin, B., Le Féon, V., Folschweiller, M., Flacher, F., Carmignac, D., Motard, E., Dajoz, I., 2016a. The proportion of impervious surfaces at the landscape scale structures wild bee assemblages in a densely populated region. Ecol. Evol. 6, 6599-6615. https://doi. org/10.1002/ece3.2374.

Geslin, B., Le Féon, V., Kuhlmann, M., Vaissière, B.E., Dajoz, I., 2016b. The bee fauna of large parks in downtown Paris, France. Ann. Soc. Entomol. Fr. 51, 487-493. https:// doi.org/10.1080/00379271.2016.1146632.

Grimm, N.B., Faeth, S.H., Golubiewski, N.E., Redman, C.L., Wu, J., Bai, X., Briggs, J.M., 2008. Global change and the ecology of cities. Science 319, 756-760.

Hall, Damon M., Camilo, Gerardo R., Tonietto, Rebecca K., Ollerton, Jeff, Ahrné, Karin, Arduser, Mike, Ascher, John S., Baldock, Katherine C.R., Fowler, Robert, Frankie, Gordon, Goulson, Dave, Gunnarsson, Bengt, Hanley, Mick E., Jackson, Janet I., Langellotto, Gail, Lowenstein, David, Minor, Emily S., Philpott, Stacy M., Potts, Simon G., Sirohi, Muzafar H., Spevak, Edward M., Stone, Graham N., et al., Threlfall, Caragh G., 2017. The city as a refuge for insect pollinators. Conserv. Biol. 31, 24-29.

Hahs, A.K., Evans, K.L., 2015. Expanding fundamental ecological knowledge by studying urban ecosystems. Funct. Ecol. 29, 863-867.

Hobson, K.A., Gibbs, H.L., Gloutney, M.L., 1997. Preservation of blood and tissue samples for stable-carbon and stable-nitrogen isotope analysis. Can. J. Zool. 75 (10) 1720-1723. https://doi.org/10.1139/z97-799.

Hobson, K.A., 1999. Tracing origins and migration of wildlife using stable isotopes: a review. Oecologia 120, 314-326.

Högberg, P., 1997. ${ }^{15} \mathrm{~N}$ natural abundance in soil-plant systems. New Phytol. 137, 179-203.

Holzschuh, A., Steffan-Dewenter, I., Tscharntke, T., 2008. Agricultural landscapes with organic crops support higher pollinator diversity. Oikos 117, 354-361. https://doi. org/10.1111/j.2007.0030-1299.16303.x.

INSEE Ile-de-France, 2013. Available at: http://www.insee.fr/fr/regions/idf/default.asp accessed 3 March 2015

Kagotani, Y., Fujino, K., Kazama, T., Hanba, Y.T., 2013. Leaf carbon isotope ratio and water use efficiency of urban roadside trees in summer in Kyoto city. Ecol. Res. 28, 725-734. https://doi.org/10.1007/s11284-013-1056-7.

Kaye, J.P., Groffman, P.M., Grimm, N.B., Baker, L. a, Pouyat, R.V., 2006. A distinct urban biogeochemistry? Trends Ecol. Evol. 21, 192-199.

Lanner, J., Kratschmer, S., Petrović, B., Gaulhofer, F., Meimberg, H., Pachinger, B., 2020 City dwelling wild bees: how communal gardens promote species richness. Urban Ecosyst. 23, 271-288. https://doi.org/10.1007/s11252-019-00902-5.

Lichtfouse, E., Lichtfouse, M., Jaffrézic, A., 2003. $\delta^{13} \mathrm{C}$ values of grasses as a novel indicator of pollution by fossil-fuel-derived greenhouse gas $\mathrm{CO}_{2}$ in urban areas. Environ. Sci. Technol. 37, 87-89. https://doi.org/10.1021/es025979y.

Liu, Z., He, C., Zhou, Y., Wu, J., 2014. How much of the world's land has been urbanized, really? A hierarchical framework for avoiding confusion. Landsc. Ecol. 29, 763-771. https://doi.org/10.1007/s10980-014-0034-y.

Lorenz, K., Lal, R., 2009. Biogeochemical C and N cycles in urban soils. Environ. Int. $35,1-8$

Mariotti, A., 1983. Atmospheric nitrogen is a reliable standard for natural ${ }^{15} \mathrm{~N}$ abundance measurements. Nature 303, 685-687. https://doi.org/10.1038/303685a0.

Mariotti, A., Lancelot, C., Billen, G., 1984. Natural isotopic composition of nitrogen as a tracer of origin for suspended organic matter in the Scheldt estuary. Geochem. Cosmochim. Acta 48, 549-555. https://doi.org/10.1016/0016-7037(84)90283-7.

Marzluff, J.M., 2005. Island biogeography for an urbanizing world: how extinction and colonization may determine biological diversity in human-dominated landscapes. Urban Ecosyst. 8, 155-175.

McDonnell, M.J., Pickett, S.T.A., 1990. Ecosystem structure and function along urban-rural gradients: an unexploited opportunity for ecology. Ecology 71, 1232-1237.

McDonnell, M., Hahs, A., 2015. Adaptation and adaptedness of organisms to urban environments. Annu. Rev. Ecol. Evol. Syst. 46, 261-280. https://doi.org/10.1146/ annurev-ecolsys-112414-054258.

McDonnell, M.J., MacGregor-Fors, I., 2016. The ecological future of cities. Science 352, 936-938. https://doi.org/10.1126/science.aaf3630.

McKinney, M.L., 2006. Urbanization as a major cause of biotic homogenization. Biol. Conserv. 127, 247-260.

McKinney, M.L., 2008. Effects of Urbanization on Species Richness: A Review of Plants and Animals. pp. 161-176. https://doi.org/10.1007/s11252-007-0045-4.

Michener, C.D., 2007. The Bees of the World. John Hopkins University Press, Baltimore \& London.

Newsome, S.D., Ralls, K., Van Horn Job, C., Fogel, M.L., Cypher, B.L., 2010. Stable isotopes evaluate exploitation of anthropogenic foods by the endangered San Joaquin kit fox (Vulpes macrotis mutica). J. Mammal. 91, 1313-1321. https://doi.org/10. 1644/09-MAMM-A-362.1.

Pataki, D.E., Tyler, B.J., Peterson, R.E., Nair, A.P., Steenburgh, W.J., Pardyjak, E.R., 2005. Can carbon dioxide be used as a tracer of urban atmospheric transport? J. Geophys. Res. Atmos. 110, 1-8. https://doi.org/10.1029/2004JD005723.

Pataki, D.E., Carreiro, M.M., Cherrier, J., Grulke, N.E., Jennings, V., Pincetl, S., Zipperer, W.C., 2011. Coupling biogeochemical cycles in urban environments: ecosystem services, green solutions, and misconceptions. Front. Ecol. Environ. 9, 27-36. https:// doi.org/10.1890/090220.

Pearson, J., Wells, D.M., Seller, K.J., Bennett, A., Soares, A., Woodall, J., Ingrouille, M.J., 2000. Traffic exposure increases natural ${ }^{15} \mathrm{~N}$ and heavy metal concentrations in mosses. New Phytol. 147, 317-326. 
Pellissier, V., Murat, A., Verfaille, F., Machon, N., 2012. Pollination success of Lotus corniculatus (L.) in an urban context. Acta Oecol. 39, 94-100.

Penick Clint, A., Savage Amy, M., Dunn Robert, R., 2015. Stable isotopes reveal links between human food inputs and urban ant diets. Proc. Biol. Sci. 282, 20142608. https://doi.org/10.1098/rspb.2014.2608.

Penick, C.A., Crofton, C.A., Holden Appler, R., Frank, S.D., Dunn, R.R., Tarpy, D.R., 2016. The contribution of human foods to honey bee diets in a mid-sized metropolis. J. Urban Econ. 2. https://doi.org/10.1093/jue/juw001.

Perkins, M.J., McDonald, R.A., Van Veen, F.J.F., Kelly, S.D., Rees, G., Bearhop, S., 2014. Application of nitrogen and carbon stable isotopes $\left(\delta^{15} \mathrm{~N}\right.$ and $\left.\delta^{13} \mathrm{C}\right)$ to quantify food chain length and trophic structure. PloS One 9. https://doi.org/10.1371/journal. pone.0093281.

Peterson, B.J., Fry, B., 1987. Stable isotopes in ecosystem studies. Annu. Rev. Ecol. Systemat. 18, 293-320.

Pouyat, R.V., Carreiro, M.M., Groffman, P.M., Pavao-Zuckerman, M.A., 2009. Investigative approaches to urban biogeochemical cycles: New York metropolitan area and Baltimore as case studies. In: McDonnell, M.J., Hahs, A.K., Breuste, J.H. (Eds.), Ecology of Cities and Towns. A Comparative Approach. Cambridge University Press, New York, USA, pp. 7462009.

Proctor, M., Yeo, P., Lack, A., 1996. The Natural History of Pollination. Collins New Naturalist Library, pp. 480.

Rankovic, A., 2016. Living the Street Life: Long-Term Carbon and Nitrogen Dynamics in Parisian Soil-Tree Systems. Doctoral thesis. Université Pierre et Marie Curie - Paris VI 2016. English. tel-01653082.

R Core Team, 2018. R: A Language and Environment for Statistical Computing. R Foundation for Statistical Computing, Vienna, Austria URL. https://www.R-project. org/.

Sattler, T., Duelli, P., Obrist, M.K., Arlettaz, R., Moretti, M., 2010. Response of arthropod species richness and functional groups to urban habitat structure and management. https://doi.org/10.1007/s10980-010-9473-2 25:941-954.

Saunders, M.E., 2018. Insect pollinators collect pollen from wind-pollinated plants: implications for pollination ecology and sustainable agriculture. Insect Conserv. Divers.
11 (1), 13-31. https://doi.org/10.1111/icad.12243.

Smith, K., Weis, D., Amini, M., Shiel, A., Lai, V., Gordon, K., 2019. Honey as a biomonitor for a changing world. Nat. Sustain. 2, 223. https://doi.org/10.1038/s41893-0190243-0.

Somme, Laurent, Vanderplanck, Maryse, Michez, Denis, Lombaerde, Isabelle, Moerman, Romain, Wathelet, Bernard, Wattiez, Ruddy, Lognay, Georges, et al., Jacquemart, Anne-Laure, 2014. Pollen and nectar quality drive the major and minor floral choices of bumble bees. Apidologie 46, 92-106.

Taki, H., Ikeda, H., Nagamitsu, T., Yasuda, M., Sugiura, S., Maeto, K., Okabe, K., 2017. Stable nitrogen and carbon isotope ratios in wild native honeybees: the influence of land use and climate. Biodivers. Conserv. 26, 3157-3166. https://doi.org/10.1007/ s10531-016-1114-x.

Wang, W., Pataki, D.E., 2010. Spatial patterns of plant isotope tracers in the Los Angeles urban region. Landsc. Ecol. 25, 35-52. https://doi.org/10.1007/s10980-009-9401-5.

Wang, W., Pataki, D.E., 2012. Drivers of spatial variability in urban plant and soil isotopic composition in the Los Angeles basin. Plant Soil 350, 323-338.

West, J.B., Bowen, G.J., Cerling, T.E., Ehleringer, J.R., 2006. Stable isotopes as one of nature's ecological recorders. Trends Ecol. Evol. 21, 408-414.

Westphal, Catrin, Bommarco, Riccardo, Carré, Gabriel, Lamborn, Ellen, Morison, Nicolas, Petanidou, Theodora, Potts, Simon G., Roberts, Stuart P.M., Szentgyörgyi, Hajnalka, Tscheulin, Thomas, Vaissière, Bernard E., Woyciechowski, Michal, Biesmeuer, Jacobus C., Kunin, William E., Settele, Josef, et al., Steffan-Dewenter, Ingolf, 2008. Measuring bee diversity in different European habitats and biogeographical regions. Ecol. Monogr. 78, 653-671.

Widory, D., 2007. Nitrogen isotopes: tracers of origin and processes affecting $\mathrm{PM}_{10}$ in the atmosphere of Paris. Atmos. Environ. 41, 2382-2390. https://doi.org/10.1016/j. atmosenv.2006.11.009.

Zurbuchen, A., Landert, L., Klaiber, J., Müller, A., Hein, S., Dorn, S., 2010. Maximum foraging ranges in solitary bees: only few individuals have the capability to cover long foraging distances. Biol. Conserv. 143, 669-676. https://doi.org/10.1016/j. biocon.2009.12.003. 